\title{
Hiroshi Sekine and Tamio KakegaI: Observation on the Sanitation of Mothers and Children at the Joboji-Machi
}

\section{浄法寺町における母子衛生の観察}

岩手医科大学第一内科学教室 (指導 工藤祐三教授)

関 根 博 - 掛 貝民 男

浄法寺町の乳児死亡率は 全国平均に比較し て非常に高く(30年, 岩手県は 全国 第 1 位. 浄法寺は岩手県第 2 位, $1000: 120)$, 大沢は この実態について，岩手県に甜ける衛生学的 調査研究第 7 報に報告している。昭和 30 年に 同町は母子保健指導特別対策地区に 指定され たので同年 8 月 8 日より 13 日まで実施した乳 児検診と共に母子衛生の観察を試み，その実 態を調查してみた。

\section{A) 町勢}

本町は県の北々西に山つて，その北々西端 は青森県に接している. 町の中心を西南端か ら東北に向つて安比川が貫流し, その真中に 中心市街が形成されている（海抜約 $200 \mathrm{~m}$ ). この本流を狭んで東西とも次第に高度を增し 海抜 $1,000 \mathrm{~m}$ 前後の高山に連なつている. そし て本流に対して東西から大体直角に各々 6 本 の支流が注ざ，丁度脊柱に対する胁骨様の状 態を呈し，その沿線に細長い平野部を形成し て, その間に 50 の部落が点在している.

1) 人口拉よび戸数.

\begin{tabular}{c|c|c|c|c}
\hline 男 $\mid 4,713$ 人 & 女 & 4,563 人 & 合 計 & 9,276 人 \\
\hline (昭和 30.9 現在） \\
\hline 戸 & 数 & 1,463 戸 \\
\hline
\end{tabular}

2) 世帯数扣よび一世帯当人数.

\begin{tabular}{|c|c|c|c|c|}
\hline & \multirow{2}{*}{ 町 } & \multirow{2}{*}{ 県平均 } & 盛岡保健所 & \multirow{2}{*}{$\begin{array}{l}\text { 䃾岡保健所 } \\
\text { 平均 }\end{array}$} \\
\hline & & & 平 均 & \\
\hline 世 带 数 & 1,456 & 250,256 & 45,821 & 16,181 \\
\hline 一世帯当数 & 6.3 人 & 5.7 人 & 5.4 人 & 5.9 人 \\
\hline
\end{tabular}

3) 職業別数.

\begin{tabular}{l|c|c|c|c|c|c|c|c}
\hline 種別 & 農業商業林業交通 サービス & 工業公ム & $\begin{array}{l}\text { その } \\
\text { 他 }\end{array}$ \\
\hline 実 数 & 896 & 140 & 120 & 50 & 25 & 15 & 110 & 100 \\
百分率 & 61.7 & 9.6 & 8.2 & 3.4 & 1.7 & 1.0 & 7.6 & 6.8 \\
\hline
\end{tabular}

4）人口密度（1 平方籸につき）

\begin{tabular}{c|c|c|c}
\hline 町 & 県平均 & 盛岡保健所平均 & 福岡保健所平均 \\
\hline 52.65 人 & 93.6 人 & 125.0 人 & 86.9 人 \\
\hline
\end{tabular}

5） 1 人当年間収入額は 22,137 円であつて， 県平均の 70,751 円に比較し 1/3である.

6) 農地面積は 1,544 町 5 反 6 畧で農家一戸 当り平均面積は 1 町 06 畧 2 分である。

7) 気温.

気温は冬季は盛岡より 幾分寒冷であるが夏 季は殆んど同程度である。

以上のように当町は, 高原寒冷, 人口密度の 低い交通文化に恵まれない地域で職業の大半 を農業に求め経済的に低く、これまでにみるべ き施策も行われずに放置された地域である。

\section{B）育児について}

乳幼児検查の際に, 生後 2 力月より 1 年半 の乳幼児の保 護者（母親） 295 名について次 の諸項目を調査した。

10 育児関心の有無

i）乳幼児の育児特よび 健康 相談を受けた ことがあるか。
ある
$19.3 \%$
ない
$80.7 \%$

\begin{tabular}{|c|c|c|c|c|c|c|c|c|c|c|c|c|}
\hline 月 & 1 & 2 & 3 & 4 & 5 & 6 & 7 & 8 & 9 & 10 & 11 & 12 \\
\hline 町 & -3.8 & -2.9 & 3.0 & 5.1 & 13.7 & 16.7 & 22.1 & 21.2 & 17.4 & 11.9 & 2.9 & -0.1 \\
\hline 盛 岡 & -4.1 & -3.2 & 3.4 & 8.3 & 14.4 & 18.2 & 22.0 & 21.9 & 18.3 & 12.4 & 4.3 & 1.0 \\
\hline
\end{tabular}




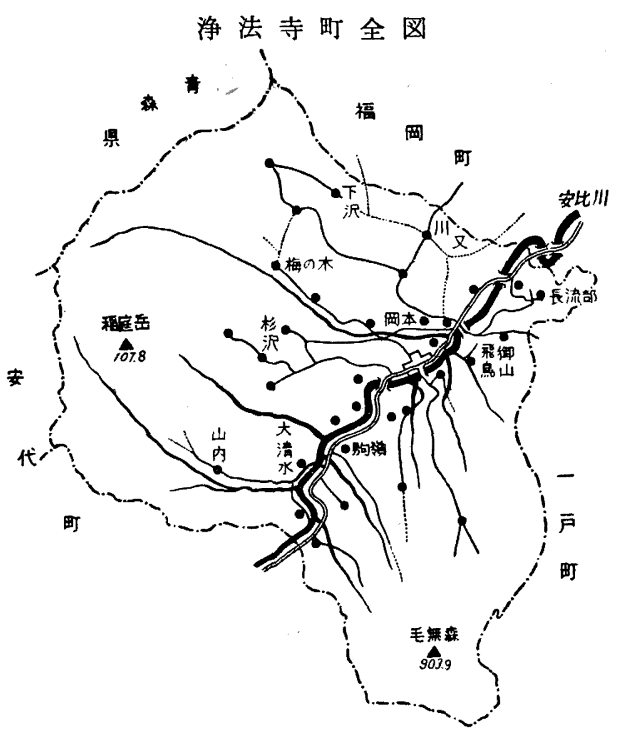

岩手県全図

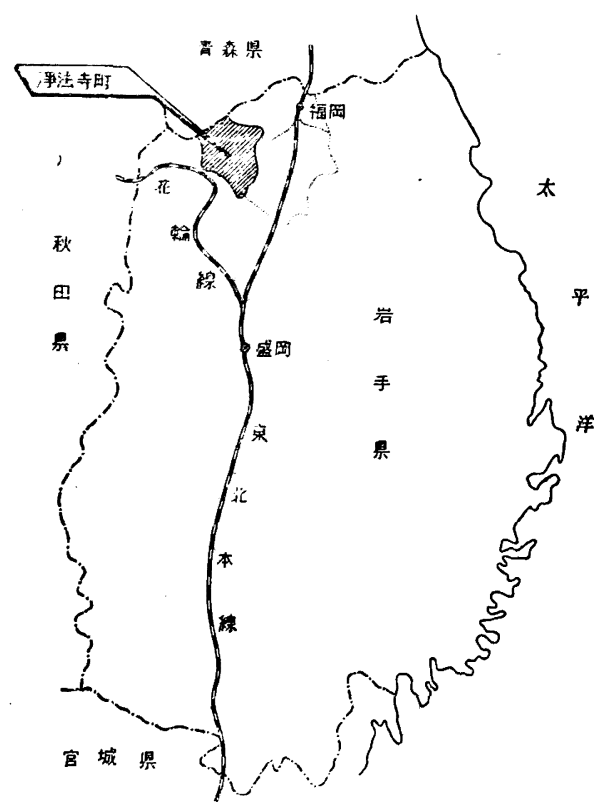

ii）授乳のため栄養, 休養, 衛生に注意して いるか.

いる $22.7 \%$ (入 浴)
いない $77.3 \%$

iii）予防注射を受けることについて。
しつている
$74.5 \%$
しらない
$25.5 \%$

2) 育児方法

i）子供の面倒は誰がタるか.

\begin{tabular}{|c|c|}
\hline 母 & $27.4 \%$ \\
\hline 父 & $2.4 \%$ \\
\hline 祖母 & $61.4 \%$ \\
\hline 祖 父 & $4.7 \mathrm{~g}$ \\
\hline その他 & 4.19 \\
\hline
\end{tabular}

祖母 $61.4 \% ， 母 27.4 \%$ と育児は祖母の仕事 であつて母は労働力で㐫る。

ii）赤ちやんを育てるのに.
えじこ
$52.0 \%$
ふとん
$42.7 \%$
その他（ハンモツク等） $5.3 \%$

えじこが $52.0 \%$ と，まだ半数以上に 利用さ れている。

iii）どんな所にねせて拉くか.

$\begin{array}{rrr}\text { へ } & \text { こ } & 9.6 \% \\ \text { ざ } & 77.6 \% \\ \text { だいどころ } & 12.8 \%\end{array}$

iv）何日に一回入浴するか.

1～3 日毎に入浴させている ものか゚，各 69, 47, 58 名で大部分であるが 1 週間に 1 回のも の44名, 10 日目に 1 回のもの 27 名, 30 日以 上に 1 回の $の 26$ 名, 入浴しないもの 5 名 は注目に值する。

v) 肌着は何日毎にとりかえるか。

vi）持むつを1 日何回とりかえるか.

特むつを全然とりか它ないるの 23 名, 1 日 1 〜2 回のもの9名あるが，これはいずれも（光 じこ）の利用者かと思われる。

3）育児の智識

i）日光浴をさせたことがあるか。

\begin{tabular}{|c|c|c|c|c|c|c|c|c|c|c|c|c|c|c|c|}
\hline 日 & 数 & 1 & 2 & 3 & 4 & 5 & 6 & 7 & 8 & 9 & 10 & 20 & 30 以上 & しない & 平均 \\
\hline & 員 & 69 & 47 & 58 & 7 & 3 & 0 & 44 & 0 & 0 & 27 & 8 & 26 & 5 & 6.4 \\
\hline
\end{tabular}




\begin{tabular}{|c|c|c|c|c|c|c|c|c|c|c|}
\hline 日 数 & 1 & 2 & 3 & 4 & 5 & $6 \sim 7$ & $10 \sim 15$ & $16 \sim 20$ & 30 以上 & 平均 \\
\hline 人 員 & 160 & 69 & 47 & 2 & 2 & 11 & 1 & 1 & 3 & 2.2 \\
\hline
\end{tabular}

\begin{tabular}{l}
\multicolumn{2}{l}{ (おむつ) } \\
\hline 回 数
\end{tabular}

\section{ある $64.9 \%$ \\ ない $35.1 \%$}

ii）赤ちやんを育てるのに次のどれが一番よ いか。

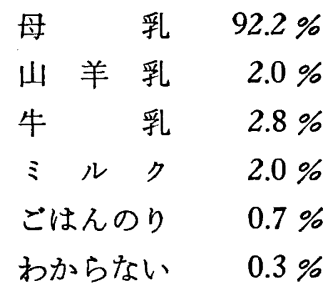

母乳以外の数值は次の母乳不足の場合と混 同したためかとも思われる。

iii）母乳が足りない時，次のどれで補いま すか。

$$
\begin{aligned}
& \text { 牛乳 } 27.8 \% \\
& \text { 山羊乳 } 15.6 \% \\
& \text { ミルク } 51.9 \% \\
& \text { ごはんのり } 4.7 \%
\end{aligned}
$$

iv）赤ちやんに乳をのませる時間を決めて いるか。

$$
\begin{array}{ll}
\text { いる } & 25.4 \% \\
\text { いない } & 74.6 \%
\end{array}
$$

v）子供が病気になつたらどうしますか。

\section{医師のところにゆく $79.3 \%$}

産婆のところにゆく $0.3 \%$

様子をみ

vi）子供の風邪つ症状.
しつている
$79.8 \%$
しらない
$20.2 \%$

\section{C）妊産婦およひ両親について}

前項と同様 295 名の母親について調查した。

1）妊娠中充分な休養，栄養がとれるか.

$$
\begin{array}{ll}
\text { とれる } & 25.2 \% \\
\text { とれない } & 74.8 \%
\end{array}
$$

2）拉産の時, 誰がとり岕げるか。

\begin{tabular}{l|r|r|c}
\hline 立会者 & 検査時 & $29.1 \sim 29.12$ & 28年全国平均 \\
\hline 医 師 & $4.4 \%$ & $1.4 \%$ & $10.1 \%$ \\
助産婦 & $81.7 \%$ & $73.1 \%$ & $85.4 \%$ \\
その他 & $13.9 \%$ & $25.4 \%$ & $4.6 \%$ \\
\hline
\end{tabular}

出産時立会者中医師, 助産婦以外のるのが, 検査時（30 年 8 月）扎よび 29 年において 13.9 $\%, 25.4 \%$ と全回平均に比較して遙かに多く， 今な和山間部に括いては「とりあげばあさん」 の風習が出る。

3) 産裖休養日数

平均 50.1 日で, 当地には「初子 80 日」と長 い休養期間を与える美風がある。

注）乳児発育と大いに関係する。

\begin{tabular}{|c|c|c|c|c|c|c|c|c|c|c|c|}
\hline 日 数 & 4 & 15 & 20 & 30 & 40 & 50 & 60 & 70 & 80 & 100 & 平均日数 \\
\hline 人員 & 1 & 2 & 6 & 33 & 63 & 82 & 68 & 28 & 8 & 3 & 50.1 日 \\
\hline
\end{tabular}

4) 両親の結婚年令

i）男は盛岡より 4 年早婚であるが，九戸と 大体一致している。

ii）女は盛岡より 2 年早婚であるが，九戸と 大体一致している.

注) 盛岡扔よび九戸の平均は昭和 28 年 8 月 千田の統計による。 


\section{（結婚年令）}

\begin{tabular}{|c|c|c|}
\hline 年令 & 父 & 母 \\
\hline 15 & 0 & 1 \\
\hline 16 & 1 & 1 \\
\hline 17 & 1 & 20 \\
\hline 18 & 9 & 58 \\
\hline 19 & 25 & 38 \\
\hline 20 & 34 & 47 \\
\hline 21 & 44 & 22 \\
\hline 22 & 19 & 21 \\
\hline 23 & 28 & 14 \\
\hline 24 & 17 & 14 \\
\hline 25 & 16 & 6 \\
\hline 26 & 11 & 8 \\
\hline 27 & 15 & 2 \\
\hline 28 & 12 & 4 \\
\hline 29 & 8 & 1 \\
\hline 30 & 6 & 1 \\
\hline 31 & 3 & 0 \\
\hline 32 & 3 & 0 \\
\hline 33 & 1 & 0 \\
\hline 34 & 5 & 0 \\
\hline 合計 & 258 & 258 \\
\hline 平均 & $23.2 \pm 3.4$ & $20.3 \pm 2.6$ \\
\hline 盛岡平均 & $27.3 \pm 2.2$ & $22.7 \pm 2.0$ \\
\hline 九戸平均 & $\begin{array}{c}23.3 \pm 4.2 \\
i \\
24.6 \pm 6.0\end{array}$ & $\begin{array}{c}20.7 \pm 2.7 \\
l_{20.8 \pm 3.3}\end{array}$ \\
\hline
\end{tabular}

5）母の年令階級別出生児数

\begin{tabular}{|c|c|c|c|c|c|}
\hline \multirow{2}{*}{ 母の年令 } & \multirow{2}{*}{ 実数 } & \multirow{2}{*}{$\begin{array}{l}\text { 子の } \\
\text { 実数 }\end{array}$} & \multicolumn{3}{|c|}{$\begin{array}{l}\text { 子供を生んだ女子1000人 } \\
\text { につき }\end{array}$} \\
\hline & & & 浄法寺 & 岩手県 & 全 国 \\
\hline $15 \sim 19$ & 7 & 7 & 1000 & 1000 & 1237 \\
\hline $20 \sim 24$ & 92 & 140 & 1522 & 1444 & 1388 \\
\hline $25 \sim 29$ & 99 & 237 & 2383 & 2275 & 1990 \\
\hline $30 \sim 34$ & 59 & 209 & 3542 & 3538 & 3064 \\
\hline $35 \sim 39$ & 30 & 136 & 4353 & 4833 & 4140 \\
\hline $40 \sim 45$ & 10 & 56 & 5400 & 5774 & 4939 \\
\hline · & 297 & 739 & & \multicolumn{2}{|c|}{ 昭 25 年度統計 } \\
\hline
\end{tabular}

6) 結婚年数と出生児数

\begin{tabular}{|c|c|c|c|c|c|}
\hline \multirow{2}{*}{ 年 } & \multirow{2}{*}{ 実数 } & \multirow{2}{*}{$\begin{array}{l}\text { 出生 } \\
\text { 児数 }\end{array}$} & \multicolumn{3}{|c|}{ 均 } \\
\hline & & & 浄法寺 & 盛 岡 & 九戸 \\
\hline $1 \sim 5$ & 119 & 182 & 1.5 & 1.4 & 1.7 \\
\hline $6 \sim 10$ & 96 & 300 & 3.1 & 2.4 & 2.8 \\
\hline $11 \sim 15$ & 21 & 92 & 4.4 & 3.8 & 4.3 \\
\hline $16 \sim 20$ & 18 & 91 & 5.1 & 6.6 & 7.1 \\
\hline $21 \sim 25$ & 6 & 44 & 7.3 & 一 & - \\
\hline $26 \sim 30$ & 1 & 10 & 10.0 & - & - \\
\hline 計 & 261 & 719 & - & - & - \\
\hline
\end{tabular}

盛岡, 九戸の平均值は昭和 28 年 8 月, 千田 の行つた統計による。

7）死亡児と母

\begin{tabular}{|c|c|c|c|c|c|}
\hline & \multicolumn{2}{|c|}{$\begin{array}{l}\text { 死亡児を持つた } \\
\text { 母 }\end{array}$} & \multicolumn{2}{|c|}{$\begin{array}{l}\text { 死亡児を持たな } \\
\text { い母 }\end{array}$} & \multirow{2}{*}{ 計 } \\
\hline & 実 数 & $\%$ & 実 数 & $\%$ & \\
\hline 浄法寺 & 70 & 26.8 & 191 & 73.2 & 261 \\
\hline 盛 岡 & - & 20.0 & - & 80.0 & - \\
\hline 九 戸 & - & $30 \sim 60$ & - & $40 \sim 70$ & - \\
\hline
\end{tabular}

盛岡, 九戸の平均は昭和 28 年千田の統計. 死亡児を持つた母は $26.8 \%$ で盛岡より多く， 九戸より少い。

\section{D）乳幼児について}

昭和 30 年 8 月 8 日より 13 日まで乳幼児検 診を実施し，該当人員 358 名中受診者 297 名 について調查した。

調査年令は生後 2 力月 より 1 年 6 力月まで の乳幼児で, 疾病異常, 身体計測, 発育状況， 栄養方法，離乳状沉等につき調査した。

1) 疾病異常について

疾病異常については

i) 受診者 297 名中 122 名で， $41.1 \%$ ある.

ii) 佝僂病質 25 名 $(20.5 \%)$, 気管支炎 28 名 (22.9\%)，臍ヘルニア拉よび 鼠径ヘルニア 20 名 $(16.4 \%)$ ，膿痂疹等皮䖉疾患 30 名 $(24.6 \%)$ ， 栄養不良 6 名 $(4.9 \%$ ) で，これらの疾患が大 部分を占めている.

これら各疾患は，前述の育児調查と大いに 関係ずけられる。 
第 1 表 身 体 計 測 1）身長

\begin{tabular}{|c|c|c|c|c|}
\hline & \multicolumn{2}{|c|}{ 男 } & \multicolumn{2}{|c|}{ 女 } \\
\hline 令 & 実 数 & 平 & 実 数 & 平 \\
\hline 2 & 6 & 63.4 & 7 & 48.7 \\
\hline 3 & 8 & 60.0 & 9 & 61.0 \\
\hline 4 & 13 & 60.8 & 5 & 59.6 \\
\hline 5 & 9 & 63.6 & 14 & 62.1 \\
\hline 6 & 8 & 64.2 & 11 & 62.0 \\
\hline 7 & 8 & 67.9 & 10 & 65.1 \\
\hline 8 & 12 & 66.4 & 9 & 65.5 \\
\hline 9 & 7 & 69.0 & 9 & 66.0 \\
\hline 10 & 7 & 67.5 & 5 & 66.5 \\
\hline 11 & 9 & 69.2 & 10 & 68.1 \\
\hline 12 & 11 & 71.9 & 3 & 70.9 \\
\hline 13 & 11 & 70.8 & 13 & 70.5 \\
\hline 14 & 13 & 73.5 & 5 & 71.6 \\
\hline 15 & 7 & 74.5 & 5 & 72.4 \\
\hline 16 & 14 & 77.7 & 8 & 75.6 \\
\hline 17 & 6 & 74.8 & 5 & 73.7 \\
\hline 18 & 9 & 76.4 & 2 & 76.8 \\
\hline
\end{tabular}

第 2 表 身 体 計 測

\section{2) 体重}

\begin{tabular}{|c|c|c|c|c|}
\hline & \multicolumn{2}{|c|}{ 男 } & \multicolumn{2}{|c|}{ 女 } \\
\hline 月令 & 実 数 & 平 & 実 数 & 平 \\
\hline 2 & 6 & 6.66 & 7 & 4.14 \\
\hline 3 & 8 & 6.70 & 9 & 5.78 \\
\hline 4 & 13 & 6.19 & 5 & 5.54 \\
\hline 5 & 9 & 6.55 & 14 & 6.21 \\
\hline 6 & 8 & 7.11 & 11 & 6.80 \\
\hline 7 & 8 & 8.16 & 10 & 6.79 \\
\hline 8 & 12 & 7.15 & 9 & 7.16 \\
\hline 9 & 7 & 7.82 & 9 & 7.00 \\
\hline 10 & 7 & 7.85 & 5 & 7.28 \\
\hline 11 & 9 & 7.85 & 10 & 7.64 \\
\hline 12 & 11 & 8.21 & 3 & 7.86 \\
\hline 13 & 11 & 8.29 & 13 & 7.70 \\
\hline 14 & 13 & 8.81 & 5 & 8.37 \\
\hline 15 & 7 & 8.89 & 5 & 8.00 \\
\hline 16 & 14 & 9.41 & 8 & 8.53 \\
\hline 17 & 6 & 8.56 & 5 & 9.20 \\
\hline 18 & 9 & 9.55 & & \\
\hline
\end{tabular}

第 3 表 浄法寺助産所新生児身長体重平均 (昭和 29 年度)

\begin{tabular}{c|cc|cc|c|c}
\hline \hline & 性 & 別 & 実 & 数 & 平 均 & 橴 準 \\
\hline 身 & 男 & 28 & 50.00 & 49.4 \\
長 & 女 & 17 & 52.23 & 48.5 \\
\hline 体 & 男 & 28 & 3.079 & 3.06 \\
重 & 女 & 17 & 3.002 & 2.95 \\
\hline
\end{tabular}

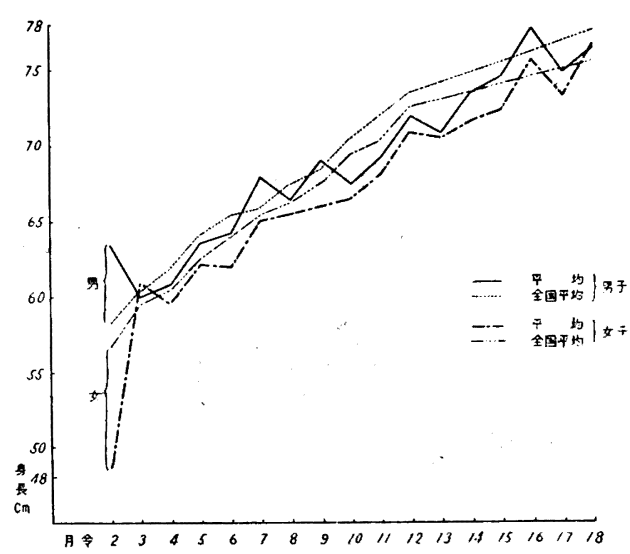

第 1 图身長

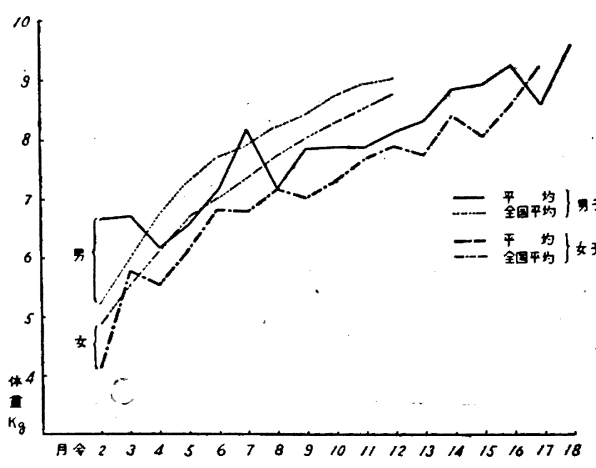

第 2 図体重

2) 身体計 測

第 1,2 表拉よび第 1 図2 のように身長体重 は男女共に 3 力月まで注全国平均を上まり，4 カ月以後は全国平均より低下している.これは 産裖休養日数（平均 50 日）と就労に関係が出 ると思われ，更に低下した体格は学令期まで 影響している。すなわち助虐所に批ける男 28 名, 女 17 名の出生時の身長, 体重の平均は第 
第 4 表 浄法寺小学校身長体重測定平均（昭和 30 年度）

\begin{tabular}{|c|c|c|c|c|c|c|c|}
\hline \multirow{2}{*}{\multicolumn{2}{|c|}{ 種 性 別 }} & 6 & 7 & 8 & 9 & 10 & 11 \\
\hline & & 1 & 2 & 3 & 4 & 5 & 6 \\
\hline 身 & 男 & $\begin{array}{c}108.4 \\
(109.9)\end{array}$ & $\begin{array}{c}114.1 \\
(115.4)\end{array}$ & $\begin{array}{c}119.9 \\
(120.6)\end{array}$ & $\begin{array}{c}124.2 \\
(125.1)\end{array}$ & $\begin{array}{c}130.0 \\
(129.5)\end{array}$ & $\begin{array}{c}134.9 \\
(134.0)\end{array}$ \\
\hline 長 & 女 & $\begin{array}{c}108.8 \\
(108.9)\end{array}$ & $\begin{array}{c}110.5 \\
(114.4)\end{array}$ & $\begin{array}{c}118.6 \\
(119.2)\end{array}$ & $\begin{array}{c}123.3 \\
(124.2)\end{array}$ & $\begin{array}{c}127.7 \\
(129.0)\end{array}$ & $\begin{array}{c}133.4 \\
(134.4)\end{array}$ \\
\hline 体 & 男 & $\begin{array}{c}18.1 \\
(18.6)\end{array}$ & $\begin{array}{c}20.5 \\
(20.6)\end{array}$ & $\begin{array}{c}23.1 \\
(23.0)\end{array}$ & $\begin{array}{c}26.9 \\
(25.2)\end{array}$ & $\begin{array}{c}28.0 \\
(27.4)\end{array}$ & $\begin{array}{c}30.8 \\
(30.0)\end{array}$ \\
\hline 重 & 女 & $\begin{array}{c}18.6 \\
(18.1)\end{array}$ & $\begin{array}{c}19.4 \\
(20.1)\end{array}$ & $\begin{array}{c}22.0 \\
(22.3)\end{array}$ & $\begin{array}{c}24.0 \\
(24.5)\end{array}$ & $\begin{array}{c}27.0 \\
(27.2)\end{array}$ & $\begin{array}{c}30.0 \\
(30.4)\end{array}$ \\
\hline
\end{tabular}

註）（）内は全国平均

第 5 表 母の年令階級別, 暦月別出産数（昭和 30 年）

\begin{tabular}{|c|c|c|c|c|c|c|c|c|c|c|}
\hline 暦月 & & & $15 \sim 19$ & $20 \sim 24$ & $25 \sim 29$ & $30 \sim 34$ & $35 \sim 39$ & $40 \sim 44$ & 計 & $\begin{array}{l}\text { 月 } \text { 別 } \\
\text { 割合 }(\%)\end{array}$ \\
\hline 総 & 数 & $\begin{array}{l}\text { 出産 数 } \\
\text { 割合 }(\%)\end{array}$ & $\begin{array}{r}9 \\
5.7\end{array}$ & $28.0^{44}$ & $\begin{array}{l}56 \\
35.7\end{array}$ & $\begin{array}{l}35 \\
22.3^{3}\end{array}$ & $\begin{array}{l}10 \\
6.4\end{array}$ & $1.9^{3}$ & $\stackrel{157}{-}$ & $\overline{-}$ \\
\hline 1 & 月 & 数 & - & 4 & 7 & 6 & - & - & 17 & 10.8 \\
\hline 2 & 月 & 数 & - & 4 & 1 & 3 & 2 & - & 10 & 6.4 \\
\hline 3 & 月 & 数 & 1 & 4 & 6 & 6 & - & 1 & 18 & 11.5 \\
\hline 4 & & 数 & - & 3 & 5 & 3 & - & - & 11 & 7.0 \\
\hline 5 & & 数 & - & 5 & 5 & 1 & 1 & - & 12 & 7.6 \\
\hline 6 & 月 & 数 & - & 3 & 5 & 1 & 3 & - & 12 & 7.6 \\
\hline 7 & 月 & 数 & 1 & 3 & 4 & 3 & 1 & - & 12 & 76 \\
\hline 8 & 月 & 数 & - & 3 & 3 & 3 & 2 & 2 & 13 & 8.3 \\
\hline 9 & 月 & 数 & 1 & 3 & 7 & 1 & - & - & 12 & 7.6 \\
\hline 10 & 月 & 数 & 1 & 4 & 6 & 2 & - & - & 13 & 8.3 \\
\hline 11 & 月 & 数 & 1 & 7 & 5 & 3 & - & - & 16 & 10.2 \\
\hline 12 & 月 & 数 & 4 & 1 & 2 & 3 & 1 & - & 11 & 7.0 \\
\hline
\end{tabular}

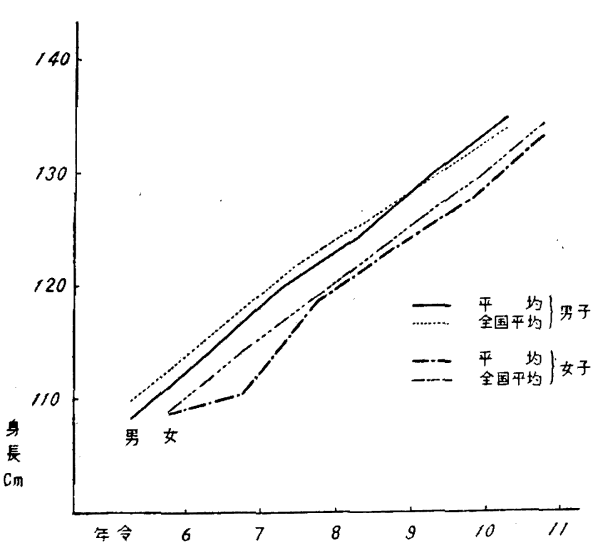

第?3 图 昭和 30 年度浄法寺小学校児童身体测定平均

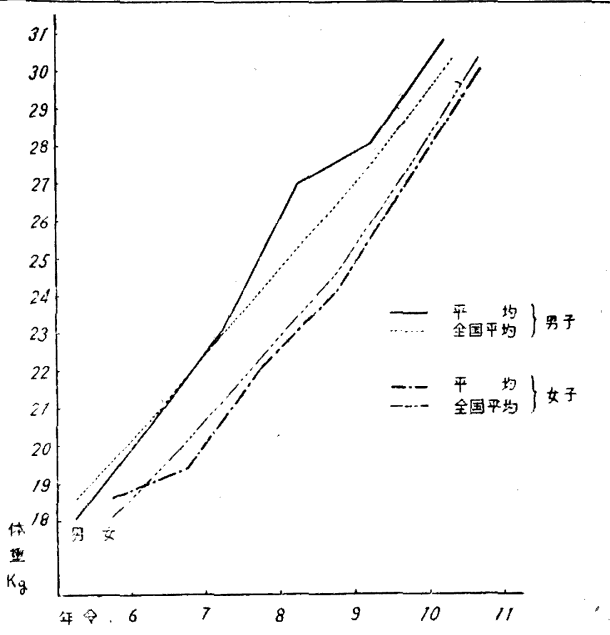

第 4 図昭和 30 年度清法寺小学校児童身体測定平开 
3 表のように男では身長 $50.0 \mathrm{~cm}$, 体重 $3.079 \mathrm{~kg}$, 女では身長 $52.2 \mathrm{~cm}$, 体重 $3.002 \mathrm{~kg}$ で全国平均 に比較してわずかに上廻る結果を示している. また浄法寺小学校の各学年の身長，体重の平 均を 29 年度の全回平均に比較すれば第 4 表第 3 図のように男子の 身長は 4 年生まで, 体重 は 2 年生まで全国平均より低く，女子の身長 体重は共に全学年を通じ全国平均以下で山る。

3）栄養方法

\begin{tabular}{|c|c|c|c|}
\hline & & 実 数 & $\%$ \\
\hline 母 & 乳 & 210 & 80.5 \\
\hline 混 & 合 & 46 & 17.6 \\
\hline 人 & 工 & 5 & 1.9 \\
\hline \multicolumn{2}{|c|}{ 計 } & 261 & \\
\hline
\end{tabular}

母乳栄養は $80.5 \%$ ，混合栄養 $17.6 \%$ ，人工 栄養 $1.9 \%$ で 8 割まで母乳栄養であるが乳児 の発育状況は産褯休養後いわゆる就労と共に 標準以下を示し, 母乳不足, 労働のための 授 乳不足（たと党ば朝昼夕 3 回の授乳）も認め

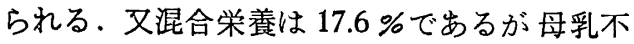
足よりはむしろ労働との関係が主である. 更 に混合，人工栄養を行つている者は洼とんど その調乳法を知らない。

4）混合栄養执よび人工栄養の種類

各種共単独使用で，併用はみられない。粉

\begin{tabular}{|c|c|c|c|c|c|}
\hline & & 混 合 & 人 I & 計 & $\%$ \\
\hline 牛 & 乳 & 6 & 1 & 7 & 13.7 \\
\hline 山 羊 & 乳 & 8 & 0 & 8 & 15.7 \\
\hline 粉 & 乳 & 31 & 4 & 35 & 68.6 \\
\hline 诨 & 粉 & 1 & 0 & 1 & 2.0 \\
\hline 計 & & 46 & 5 & 51 & \\
\hline
\end{tabular}

乳は $68.6 \%$ で最も多く, 牛乳は $13.7 \%$, 山羊 乳は $15.7 \%$ であるがほとんど自家飼育による

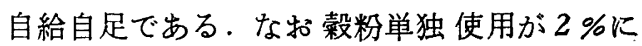
みられる。

5）離乳について

生後 5 力月以後の乳幼児 206 名中離乳を行 つたるの 104 名 $(50.5 \%$ ) 離乳を行わないる の 102 名 $(49.5 \%)$, 標準の 7 力月で離乳を開 始している者は $16.0 \%$ \%゙る.

1 年 2 力月で,なお $50.5 \%$ 離乳開始状況 で非常に遅れている。

6）発育について

i) 生歯開始状況.

5 力月以後の乳幼児 241 名中生歯開始 した るの 178 名 $(73.1 \%)$ ，標準 7 カ月で生歯を開 始しているものは $34.1 \%$ で約 $1 / 3$ に過ぎず， 1 年で $72.7 \%$ とはなはだ遅れている.

ii）歩行開始状況.

11 力月以上の 乳幼児 132 名中歩行開始した （離 乳）

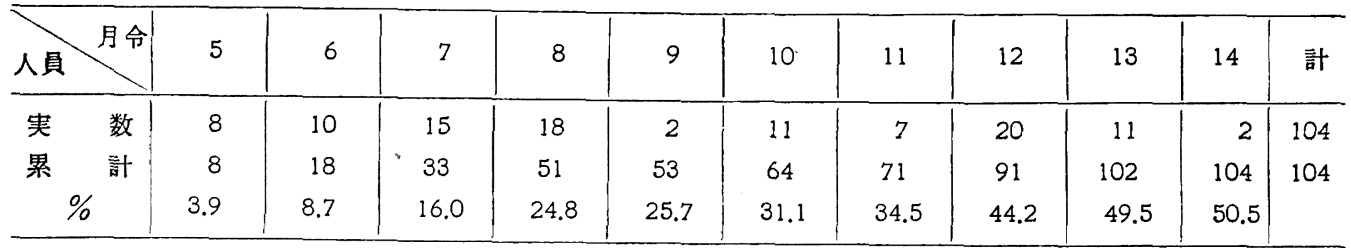

\begin{tabular}{r|c|c|c|c|c|c|c|c|c|c}
\hline (生 宷) & & & & & \\
\hline 月令 & 5 & 6 & 7 & 8 & 9 & 10 & 11 & 12 & 13 以上 & 計 \\
\hline $\begin{array}{c}\text { 発生実数 } \\
\%\end{array}$ & 9 & 23 & 51 & 45 & 20 & 13 & 10 & 6 & 1 & 178 \\
\hline
\end{tabular}

\begin{tabular}{|c|c|c|c|c|c|c|c|c|}
\hline & 11 & 12 & $\begin{array}{l}1 \text { 年 } \\
1 \text { 力音 } \\
\end{array}$ & $\begin{array}{l}1 \text { 年 } \\
2 \text { 力月 }\end{array}$ & $\begin{array}{l}1 \text { 年 } \\
3 \text { 力月 } \\
\end{array}$ & $\begin{array}{l}1 \text { 年 } \\
4 \text { 力月 } \\
\end{array}$ & $\begin{array}{l}1 \text { 年 } \\
5 \text { 力月 }\end{array}$ & 計 \\
\hline & 5 & 20 & 8 & 10 & 5 & 3 & 3 & 54 \\
\hline$\%$ & 3.8 & 18.9 & 25.0 & 32.6 & 36.4 & 38.6 & 40.9 & \\
\hline
\end{tabular}


第 6 表 性別, 妊娠月数別, 出生時の体重別出生児数, 総数に対する割合及び平均体重（昭30年）

\begin{tabular}{|c|c|c|c|c|c|c|c|c|c|c|c|c|c|}
\hline $\begin{array}{l}\text { 妊娠 } \\
\text { 月数 }\end{array}$ & & 総数 & $\begin{array}{l}1.0 \mathrm{~kg} \\
\text { 末満 }\end{array}$ & $1.0 \sim 1.5$ & $1.5 \sim 2.0$ & $2.0 \sim 2.5$ & $2.5 \sim 3.0$ & $3.0 \sim 3.5$ & $3.5 \sim 4.0$ & $4.0 \sim 4.5$ & 不詳 & 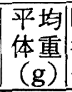 & $\mid \begin{array}{l}\text { 昭和 } 30 \\
\text { 年全国 } \\
\text { 平均 }\end{array}$ \\
\hline 総数 & 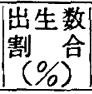 & 157 & $\begin{array}{r}1 \\
0.6\end{array}$ & 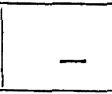 & $\begin{array}{r}2 \\
1.2\end{array}$ & $\begin{array}{r}7 \\
4.5\end{array}$ & $\begin{array}{c}52 \\
33.1\end{array}$ & $\begin{array}{r}77 \\
49.0\end{array}$ & $8.3^{13}$ & $\begin{array}{r}1 \\
0.6\end{array}$ & 4 & 2,784 & 3,111 \\
\hline
\end{tabular}

男

\begin{tabular}{|c|c|c|c|c|c|c|c|c|c|c|c|c|c|}
\hline 総数 & 数 & 83 & - & - & $\begin{array}{r}2 \\
2.5\end{array}$ & $\begin{array}{r}2 \\
2.5\end{array}$ & $\begin{array}{r}29 \\
35.8\end{array}$ & $\begin{array}{r}39 \\
48.1\end{array}$ & $\begin{array}{r}9 \\
11.1\end{array}$ & - & $\frac{2}{-}$ & $3,037 \mid$ & 3,152 \\
\hline 7カ月 & . & 1 & - & - & 100.0 & - & - & - & - & - & $\cdots$ & 1,680 & 1,587 \\
\hline 8カ月 & 数 & 1 & - & - & 100.0 & - & - & - & - & - & - & 1,900 & 1,957 \\
\hline 9カ月 & 数 & 1 & - & - & - & $\begin{array}{r}1 \\
100.0\end{array}$ & - & - & - & - & - & 2,360 & 2,487 \\
\hline 10力月 & 数 & 78 & - & - & - & $\begin{array}{r}1 \\
1.3\end{array}$ & $\begin{array}{c}29 \\
37.2\end{array}$ & $\begin{array}{c}39 \\
50.0\end{array}$ & $\begin{array}{r}9 \\
11.5\end{array}$ & - & & 3,077 & 3,188 \\
\hline
\end{tabular}

女

\begin{tabular}{|c|c|c|c|c|c|c|c|c|c|c|c|c|c|}
\hline 総数 & 数 & 4ㅜ & $\begin{array}{r}1 \\
1.4\end{array}$ & - & - & $\begin{array}{r}5 \\
6.9\end{array}$ & $\begin{array}{r}23 \\
31.9\end{array}$ & $\begin{array}{r}38 \\
52.8\end{array}$ & $\begin{array}{r}4 \\
5.6\end{array}$ & $\begin{array}{r}1 \\
1.4\end{array}$ & $\underline{2}$ & 2,499 & 3,068 \\
\hline 7カ月 & 数 & 1 & $\begin{array}{r}1 \\
100.0\end{array}$ & - & - & - & - & - & - & - & - & 740 & 1,554 \\
\hline 8カ月 & 数 & $\underline{0}$ & - & - & - & - & - & - & - & - & - & - & 1,906 \\
\hline 9カ月 & 数 & 1 & - & - & - & 100.0 & - & - & - & - & - & 2,200 & 2,425 \\
\hline 10カ月 & 数 & - & - & - & - & $\begin{array}{r}4 \\
5.7\end{array}$ & $\begin{array}{c}23 \\
32.9\end{array}$ & $\begin{array}{c}38 \\
54.3\end{array}$ & $\begin{array}{r}4 \\
5.7\end{array}$ & $\begin{array}{r}1 \\
1.4\end{array}$ & - & $2,529 \mid$ & 3,102 \\
\hline
\end{tabular}

もの 54 名で, 標準の 1 年 1 カ月に開始してい るものは $25.0 \%$ と非常に少い。

1 年 5 カ月に拈いて $40.9 \%$ と半数にみたな い程遅れている。

\section{E) 出産状況について}

昭和 30 年 1 月から 12 月 までの出産状況を 次の項目について調查してみた。

i）母の年令階級別，暦月別出産数.

第 5 表のように年令別では 25〜29 才が 35.7 $\%$ で第 1 位, 以下 $20 \sim 24$ 才の $28.0 \%, 30 \sim 34$ 才の $22.3 \%$ で全回平均に一致し，20３4才の 年令層が総数の $85.9 \%$ を占めている.

季節的变動についてみれば，全国平均が毎 年のように 1 月に最も多く, 以後次第に減少 して 6 月に最も少く， 7 月以後やや增加して 10月以後再び減少する傾向を示しているのに
対して本調查では, 3 月 $11.5 \%$ 最す多く,つ いで 1 月，11月の順で 2 月が最少であつた。

ii）出生児の体重.

性別, 妊娠月数別, 出生児の体重別出生児 数については表 6 にみるように総数，性別共 に $3.0 \sim 3.5 \mathrm{~kg}$ の割合が最も多く, 総数で 49 $\%$ ，性別では男 $48.1 \%$ ，女 $52.8 \%$ あ゙あた。

妊娠 10 力月の出生児についてみれば 3.0〜 $3.5 \mathrm{~kg}$ が最も多く男 $50 \%$ ，女 $54.3 \%$ を占めて いる.

統計的に未熟児と言われる $2.5 \mathrm{~kg}$ 未満は女 に $1.4 \%$ （妊娠 7 力月）みられたが，妊娠10力 月では男女共にみられない。

平均体重は, 総数では男 $3.037 \mathrm{~g}$ ，女 $2.499 \mathrm{~g}$ であり，妊娠 10 力月では男 $3.077 \mathrm{~g}$ ，女 $2.529 \mathrm{~g}$ で昭和 30 年全国平均に比較与れば男女共に下 
廻つている。

iii）死産について.

死産は総数 4 で，出産数 との割合は $2.5 \%$ である。季節の变動についてこれを見れば， 5,6 月が各 1 件, 7 月 2 件を占め，昭和 30 年 全国平均死産率に拄いては 5 9 月が高く, 特 に7 月が最高率であるが，本調査に扮いても 同じような傾向がみられる。

iv）年令招よび分婏回数と弛緩性出血.

\begin{tabular}{|c|c|c|c|c|c|c|}
\hline \begin{tabular}{ll|} 
分婏 & 年令 \\
回数
\end{tabular} & $\begin{array}{l}16 \sim \\
19\end{array}$ & $20 \sim$ & 25 & $\begin{array}{l}30 \sim \\
34\end{array}$ & 計 & $\begin{array}{c}\text { 分婊回数別出 } \\
\text { 産数之の割合 } \\
(\%)\end{array}$ \\
\hline I & 1 & 1 & - & - & 2 & 5.3 \\
\hline 【I & - & 1 & I & - & 2 & 6.9 \\
\hline $\mathbb{N}$ & - & - & 1 & 1 & 2 & 7.1 \\
\hline VI & - & - & 1 & - & 1 & 14.3 \\
\hline 計 & 1 & 2 & 3 & 1 & 7 & \\
\hline 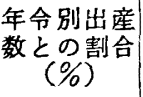 & 11.1 & 4.5 & 5.4 & 2.9 & & \\
\hline
\end{tabular}

年令別出産数との割合では 16〜19才の若年 者䅉に扮いて $11.1 \%$ \%占めて高く，35才以上 ではない.出産総数との割合は $4.5 \%$ である.

分婏回数別出産数との割合では，1，2，4回 に抒いてはいずれも5〜7\%であり，6回では $14.3 \%$ と多く, 本調查では分婏回数に 比例し てその割合が高くなつている。

\section{むすび}

昭和 30 年に本町が母子保健指導特別対策地 区に指定された機会に同年 8 月乳幼児の検診 を実施し，岁わせて母子衛生の実態を調査し てみた。

1）育児その他について

生後 2 カ月より 1 年半の乳幼児の母 295 名 についての調査成績.

育児に無関心

$80.7 \%$

保育者が祖父母の場合 $\quad 66.1 \%$

えじこの利用

$52.0 \%$

入浴日数

6.4 日に 1 回

肌着の交換

2.2 日に 1 回

扣むつの交換

産䘿就床日数

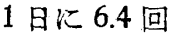

妊娠中の俨休堽
50 日

$74.8 \%$
医師助産婦外の出産立会者 $13.9 \%$

以上主なるのについて列記したが育児に関 しては多くの問題を残している.

2) 乳幼児について

生後 2 カ月より 1 年半の乳幼児 297 名の調 查成績.

1）疾病異常：122名 (41.1\%)。何僂病質 $20.5 \% ，$ ヘ $=$ フ $16.4 \%$ ，気管支炎 $22.9 \%$ ， 膿痂疹 $11.5 \%$.

口）身体計測：助産所に括ける出生時の身 長, 体重の平均は昭和 29 年度に拈いて男児 $50.0 \mathrm{~cm}, 3.079 \mathrm{~kg}$ ，女児 $52.2 \mathrm{~cm}, 3.002 \mathrm{~kg}$ で全 国平均に比し幾分高く，男女共に 3 力月以後 で全国平均に比較して減少を示し，これが学 龄期まで影響している。

八）栄養方法：

母乳栄養 $80.5 \%$ 混合栄養 $17.6 \%$

人工栄養 $1.7 \%$

混合，人工栄養の種類は

粉乳 $68.6 \%$ ，牛乳 $13.7 \%$ ，山羊乳 $15.7 \%$ ， 款粉 $2.0 \%$ で各種とも単独使用である.

））発育状況：全回平均 7力月の生歯か3 34.1 $\%$ ，全国平均 1 年 1 力月の歩行開始が $25 \%$ で 遅延が著しい。

なお 7 カ月離乳開始は $16 \%$ \%ある。

ホ）両親の結婚年令：男 $23.2 \pm 3.7$ 才，女 $20.3 \pm 2.6$ 才で都市よりあ早婚である。

一）死亡児を持つた母は $26.8 \%$ \%゙都市より 多い。

3) 出産状況

1）出生時の体重：昭和 30 年度に括いては 平均体重 $2.784 \mathrm{~g}$ で全国平均 $3.11 \mathrm{~g}$ より低い。

口) 死産扰よび後出血：出産総数に対して 死産は $2.5 \%$ ，弛緩性出血は $4.5 \%$ の割合でみ られた。

\section{主要文献}

1) 岩手県厚生部, 䧸生年報, 盛岡, 昭 30 . (昭 33)

2) 大沢武夫：日本公橖誌，6巻 1 号，(昭 34)

3）厚生の指針，特集国民䛔生の動向，愿生統計協 会, 6 巻 10 号, (昭 34)

4）人口動態統計, 厚生省, (昭 30)

5）千田耕作：小胃保健研究，13 巻 2 号，昭 (29) 
mentioned. 4) There were no correlation observed among the threshold ol sensorium, darkness of skin color, socalled vitamin C cutane resction, copper contents of serum, and iron contents of serum.

(From the Department of Hygiene, Fukushima Medical College, Fukushima)

Observation on the Sanitation of Mothers and

Children at the Joboji-Machi

By

Hiroshi SEKINE and Tamio KAKEGAI

As the mortality of infant at the Joboji-machi was very high as compard with national mean value, this town was appointed as the special district for sanitaly guaidance of mothers and children in 1955.

The Preesent author conducted an examination for infants and studied on the actual sanitory condition of mothers and children in August 1955.

1) On the infantile nursing and the other items.

The results of the reseach on 295 mothers who have infants 2 months to 1 year and half aiter bjrth.

Indifference of the infant nursing ......................... $80.7 \%$

Nurse is grandparents.....................................66.1\%

Use of "Ejiko" =a cracel .................................52.0\%

Days of taking bath............................... once in 6.4 days

Change of underwear............................. once in 2.2 days

Change of diaper................................. 6.4 in a day

Days of puerperium ....................................50 days

No holiday during pregnancy...............................74.8\%

Witness of birth except doctor and midwife................13.9\%

2) On the infant.

The result of the research on 297 infants from 2 months to 1 year and half after birth.
a) Illness
122 infants $(41.1 \%)$
Rachitis constitution.
$.20 .5 \%$
Harnia $16.4 \%$
Bronchitis
$.22 .9 \%$
Impetigo
$.11 .5 \%$

b) Body measurement.

Stature and weight on the birth at maternity clinic was a little higher than 
national mean value and it was a slight dicrease to school age from a threemonth old baby.

c) The manner of nutrition.

Breast milk...................80.5\% Artificial feeding ...... 1.7\%

Mixed feeding..................22.9\%

d) The state of development.

Dentition (at a seven-month old baby of the national value.)... $.34 .1 \%$

Walking start (at a thirteen-month old baby of the national mean value.) $\cdots 25 \%$

Weaning start (at a seven-month old baby.)

$16 \%$

e) Marriage of parents was earlier then that of the city people.

Male ..................................23.2 \pm 3.7 years old

Female ..............................20.3 22.6 years old

f) Mother of the dead child were $26.8 \%$ more then that of the city people.

3) On the state of birth.

a) The body weight on the birth was lower that of the national meal value.

b) The rote stillbirth was $2.5 \%$ and the birth after bleeding was $4.5 \%$.

(From the Department of Internal Medicin, I st Division,

Iwate Medical College, Morioka) 